\title{
The effect of plant biomass and interval of water application on water use efficiency and yield of sweet corn (Zea mays L. var. saccharata Sturt)
}

\author{
I.N.P. SOETEDJO \\ Department of Agro technology, Faculty of Agriculture, Universitas Nusa Cendana, Jl. Adisucipto, Penfui, Kupang 85148, East Nusa Tenggara, \\ Indonesia. Tel./Fax. +62-380-881085, email: prijo_2005@yahoo.com
}

Manuscript received: 15 March 2016. Revision accepted: 22 April 2017.

\begin{abstract}
Soetedjo INP. 2017. The effect of plant biomass and interval of water applications on water use efficiency and yield of sweet corn (Zea mays L. var. saccharata Sturt). Trop Drylands 1: 32-35. The main problem in dryland farming system is the loss of water during crop growth and development. The use of organic matters such as paddy straw, paddy husk, and biomass of Gliricidia and Chromolaena has been proved to minimize water loss. Moreover, water use efficiency can be improved by applying water based on the crop growth stage. The main objective of the research was to determine the interaction effect of different buried crop biomass and interval of water application on water use efficiency and yield of sweet corn (Zea mays L. var. saccharata Sturt). The research was assigned in factorial treatment laid out in Randomized Completely Block Design with 3 replicates. The research results showed no interaction effect of the treatment combinations on soil water content, water use efficiency, and yield of sweet corn. Each of the single factors of the kind of biomass and water application interval, however, significantly affected water use efficiency and yield of sweet corn. Buried paddy straw produced the highest yield and water use efficiency of sweet corn $\left(750.66{\left.\mathrm{~g} 3 \mathrm{~m}^{-2}\right)}^{2}, 14.21 \%\right)$. Moreover, three days of water application interval resulted in higher yield and water use efficiency of sweet corn $\left(654.5 \mathrm{~g} 3 \mathrm{~m}^{2(-1)}, 14.68 \%\right)$.
\end{abstract}

Keywords: Crop biomass, water applications, water content, water use efficiency, sweet corn

\section{INTRODUCTION}

Sweet corn (Zea mays L. var. saccharata Sturt) is one of the major food crops currently widely grown in East Nusa Tenggara Province, Indonesia. This crop has a high carbohydrate content, low protein and fat, and sweet taste. However, the productivity in sweet corn cultivation varies with the yield depending strongly on soil nutrients and water availability. Meanwhile, the availability of soil nutrients and water becomes the main constraint in East Nusa Tenggara. These constraints could be overcome by practicing farming system that might be able to minimize water loss and improve the availability of nutrients.

The application of organic matters, such as paddy straw, paddy husk, Gliricidia, and Chromolaena biomass is a promising way to improve the availability of soil nutrients and water. This is mainly because these sources of organic matter contain lignin, silica, cellulose, and organicC, which might be able to improve soil bulk density, porosity, and water holding capacity (Arsyad 2010). Some studies showed that the use of organic matters, such as stems of corn, sorghum, and paddy husk has the capability to improve soil aeration, and soil water holding capacity. Some organic matters, such as waste of Gliricidia (Gliricidia zepium) and kirinyu (Chromolaena odorata), could increase the availability of Phosphorus, and organic-C content. Moreover, it was shown that organic-C content could improve soil water holding capacity (Tisdale et al. 1985; Praktino et al. 2002; Ajidirman, 2010).

All organic matters can be applied by either spreading them on the soil surface or burying them under the soil.
However, burying organic matter under the soil might be more efficient as it is able to reduce evapotranspiration and increase decomposition processes (Puspareny et al. 2008). A previous study by Makarim et al. (2007) showed that burying paddy straw was able to improve the efficiency of soil water holding capacity, resulting in an increase of yield of maize by $22 \%$. Moreover, the efficiency of water holding capacity and water use by crops might be improved by arranging the time of water application. Some studies showed that the use of water by crop depends strongly on the crop growth stages and physical characteristics of the soil. Therefore, optimal water application might significantly affect the nutrient absorption, which then affects the growth and yield of the crop, if water is applied based on the crop water requirement.

Based on all those mentioned study results, this research was conducted to know the interaction effect of different kinds of buried plant biomass (i.e., paddy straw, paddy husk, Gliricidia, and Chromolaena) and interval of water application (daily, every 3 days, every 5 days) on soil water content, yield of sweet corn and water use efficiency.

\section{MATERIALS AND METHODS}

The present research was conducted in East Penfui village, Central Kupang Sub-District, Kupang District from August to November 2014. The research used Factorial research design which was laid out in Randomized Completely Block Design with three replications. Two treatment factors were assigned, namely kinds of buried 
biomass (i.e. paddy straw, paddy husk, Gliricidia, and Chromolaena) and interval of water application (daily, every 3 days, every 5 days).

Variables observed in the present study included the nutrient content of the biomass, water use, water use efficiency, and yield of sweet corn. Nutrient contents of the biomass were analyzed 2 weeks before their application into the soil. The observed nutrient content of buried biomass included organic- $\mathrm{C}$ content, total $\mathrm{N}$ content, and the available $\mathrm{P}$ content. Organic- $\mathrm{C}$ content was measured by using ashing method (Walkley 1947), total N (\%) content was measured by using semi-automatic Kjedhal digestion (AOAC 1975), and the availability of $\mathrm{P}$ (ppm) was measured by using Olsen method (Olsen et al. 1954). Water use was measured based on soil water content (i.e. early growth stage, maximum vegetative growth stage, and harvesting stage) by using gravimetric method (SSIR 1984). All collected data were subjected to analyses of variance, followed by a post hoc test of Duncan Multiple Range test (DRMT) at 5\% level (Steel and Torie 1989) to compare the treatment means.

\section{RESULTS AND DISCUSSION}

\section{Organic-C content of buried biomass}

The results of present study showed that Gliricidia biomass contained a higher organic-C $(41.0 \%)$ compared to others buried biomass. Meanwhile, paddy straw had the highest content of $\mathrm{C} / \mathrm{N}$ ratio $(61.0 \%)$ (Table 1$)$. The ratio of $\mathrm{C} / \mathrm{N}$ significantly determined the time of decomposition process in which high $\mathrm{C} / \mathrm{N}$ ratio will cause a longer decomposition process. This is mainly due to increasing content of lignin and cellulose as result of high $\mathrm{C} / \mathrm{N}$ ratio. Moreover, it might improve water holding capacity.

\section{Water use}

Results of the present study revealed that there was no significant interaction effect between the kinds of buried biomass and the interval of water application on total water use during crop growth stage. However, water use was significantly affected by the single treatment factors of kinds of buried biomass and interval of water application (Table 2).

Results of DRMT at 5\% level of data of the single factor on the kinds of buried biomass showed that paddy straw was capable of decreasing the water used by sweet corn during growth stage as compared to other kinds of biomass. This is mainly due to paddy straw having a higher content of $\mathrm{C} / \mathrm{N}$ ratio, resulting in a better capability to hold the available soil water content. In addition, this biomass is also able to minimize water loss through soil evaporation. Our finding is in line with some studies showing that paddy straw was able to improve soil water holding capacity (Makarim et al. 2007; Murdolelona et al. 2008). Meanwhile, buried Gliricidia biomass increased water use significantly during the crop growth stage. This is mainly because buried Gliricidia biomass has a lower $\mathrm{C} / \mathrm{N}$ ratio content compared to that of other kinds of biomass. This low $\mathrm{C} / \mathrm{N}$ ratio caused a lower capability in improving soil water holding capacity.
Table 1. Nutrient content of paddy straw, paddy husk, Chromolaena, and Gliricidia biomass

\begin{tabular}{lcccc}
\hline $\begin{array}{c}\text { Kinds of } \\
\text { biomass }\end{array}$ & N & P & $\begin{array}{c}\text { C- } \\
\text { Organic }\end{array}$ & C/N \\
\hline Paddy straw & 0.64 & 0.15 & 39.3 & 61.00 \\
Paddy husk & 0.94 & 2.40 & 33.6 & 35.74 \\
Chromolaena & 2.65 & 0.53 & 38.6 & 14.56 \\
Gliricidia & 3.13 & 0.22 & 41.0 & 13.00 \\
\hline
\end{tabular}

Table 2. The effect of various buried biomass and interval of water application on water use of sweet corn during the growth stage

\begin{tabular}{lll}
\hline Treatment & Water use $(\mathbf{m}$ \\
\hline Kinds of biomass & & \\
Paddy straw & & \\
Paddy husk & 630.53 & a \\
Chromolaena & 630.58 & b \\
Gliricidia & 630.60 & b \\
& 630.62 & c
\end{tabular}

\begin{tabular}{lrl} 
Water application interval & & \\
Daily & 1092.62 & $\mathrm{c}$ \\
3 days & 445.76 & $\mathrm{~b}$ \\
5 days & 353.37 & $\mathrm{a}$ \\
\hline
\end{tabular}

Note: Values in the same treatment followed by different letter at the same column means significantly different at Duncan Multiple Range Test $5 \%$ level

Analysis of variance of data on the interval of water application showed that daily water application resulted in significantly higher water use during crop growth stage as compared to other water application intervals. This is mainly due to daily water application being able to increase soil water content and crop water availability. Meanwhile, soil water content tended to be low when the watering was applied in every 3 and 5 days intervals. As a result, the crop might have used water less than it should be to support the crop growth and yield.

\section{Yield of sweet corn}

Results of the present research showed no significant interaction effect between kinds of buried biomass and water application interval on yield of sweet corn. However, the single treatment factor of either kind of biomass or water application interval significantly affected sweet corn yield (Table 3 ).

Comparison of the treatment means using DMRT post hoc test at 5\% level revealed that the highest yield of sweet corn was achieved by the application of buried paddy straw, which was then followed by paddy husk, Chromolaena odorata, and Gliricidia (Table 3). The high sweet corn yield produced by buried paddy straw was mainly due to the fact that this kind of biomass is able to improve physical characteristics of the soil, resulting in the availability of water content. This condition might have improved the number of soluble nutrients and nutrients exchange in supporting the growth and yield of sweet corn. In contrast, the biomass of Gliricidia that was buried into 
the soil was more easily decomposed, which might have resulted in a lower soil water holding capacity, a lower number of soluble nutrients and nutrients exchange. Previous studies (e.g. Agustina 2007; Adirman 2010; Arsyad 2010) demonstrated that buried biomass with a high content of $\mathrm{C}$ organic was able to improve soil physical characteristics, increase water holding capacity 2-3 times their weight, and increase soil water content up to $43 \%$.

Our data on the single factor treatment of water application interval also showed that daily water application significantly resulted in a higher yield of sweet corn compared to other treatments (Table 3). This result is related to better soil water availability, better soluble nutrient content, and better nutrient absorption of this treatment to support growth and yield of sweet corn.

\section{Water use efficiency}

The present study results revealed no interaction effect of kinds of buried biomass and interval of water application on water use efficiency. However, each of the two single treatment factors caused a significant effect on water use efficiency of sweet corn.

Analysis of data of the single treatment factor on the kinds of buried biomass showed that paddy straw and paddy husk provided a higher water use efficiency as compared to buried Gliricidia biomass (Table 4). This is mainly due to the high $\mathrm{C} / \mathrm{N}$ ratio of paddy straw and paddy husk biomass, resulting in longer decomposing processes of the biomass by the microorganism. The biomass of paddy straw and paddy husk could increase water holding capacity of the biomass and the soil. Some studies showed that yield of the crop could be improved by 1.5-2 higher than their yield potential as a result of the increase of soil water holding capacity (Adirman 2010; Arsyad 2010).

Furthermore, the 3 days and 5 days intervals of water application were more efficient than daily water application (Table 4). This is mainly because soil water availability of either 3 days or 5 days water application intervals was lower than that of daily water application, however, crop yield of sweet corn irrigated every day was higher than that of 3 and 5 days irrigation intervals. This implies that better water use efficiency is not always correlated with a better yield of sweet corn. Previous studies showed that improvement of crop water use efficiency depends strongly on the capability of the crop in using water and soluble nutrients in supporting their growth and yield (Islami and Utomo, 1995 and Supriadi 2008).

Based on the present study results, several conclusions were made as follows: (i) There was no interaction effect between the kinds of buried plant biomass and the interval of water application on water use, the yield of sweet corn, and water use efficiency, but each of the single treatment factors significantly affected the observed variables. (ii) Within the single treatment factor of kinds of biomass, buried paddy straw provided the lowest water use, the highest sweet corn yield, and the most efficient water use. (iii) Within the single factor treatment of water application interval, 3 days water application interval provided the lowest water use, the highest yield of sweet corn, and the most efficient water use.
Table 3. The effect of various buried biomass and interval of

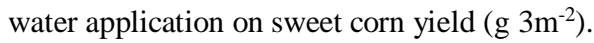

Treatment Sweet corn yield $\left(\mathrm{g} \mathrm{3m}^{-2}\right)$

$\begin{array}{lll}\text { Kinds of biomass } & & \\ \text { Paddy straw } & 750.77 & \mathrm{~b} \\ \text { Paddy husk } & 683.33 & \mathrm{~b} \\ \text { Chromolaena } & 630.00 & \mathrm{ab} \\ \text { Gliricidia } & 561.00 & \mathrm{a}\end{array}$

Water application interval

Daily

3 days

$752.25 \mathrm{c}$

$654.50 \mathrm{~b}$

5 days

$562.00 \quad$ a

Note: Values in the same treatment followed by different letters at the same column means significantly different at Duncan Multiple Range Test $5 \%$ level.

Table 4. The effect of various buried biomass and interval of water application on water use efficiency.

\begin{tabular}{lrl}
\hline Treatment & Water use effici \\
\hline Kinds of biomass & & \\
Paddy straw & & \\
Paddy husk & 14.22 & $\mathrm{~b}$ \\
Chromolaena & 13.01 & $\mathrm{~b}$ \\
Gliricidia & 11.89 & $\mathrm{ab}$ \\
& 10.81 & $\mathrm{a}$
\end{tabular}

$\begin{array}{llrl}\text { Water } & \text { Application } & & \\ \text { Interval } & & \\ \text { Daily } & 6.88 & \text { a } \\ \text { 3 days } & 14.68 & \text { b } \\ 5 \text { days } & 15.90 & \text { b }\end{array}$

Note: Values in the same treatment followed by different letter at the same column means significantly different at Duncan Multiple Range Test 5\% level.

\section{ACKNOWLEDGEMENTS}

The author thanks Yanto for his contributions to this research.

\section{REFERENCES}

Ajidirman. 2010. Study on restoration of soil organic-C and its relation to soil physical properties under palm oil tree. Journal Agronomi 10 (2): 81-84. [Indonesian]

AOAC. 1975. Official Methods of Analysis Association of Official Agricultural Chemists, 12th Ed, Washington DC, p 564-596.

Arsyad S. 2010. Soil and Water Conservation. IPB Press, Bogor. [Indonesian].

Arsyad AR, Farni, Ermadani Y. 2011. Application of green fertilizer (Calopogonium mucunoides and Pueraria javanica) to the availability of water and soybean yield. Journal Hidrolitan 2(1): 31-39. [Indonesian].

Islami T, Utomo WH. 1995. Water, Soil, and Plant Relationship. IKIP Semarang Pres, Semarang. [Indonesian].

Makarim AK, Suyarno, Sumanto. 2007. Paddy Husk. Management and Utilization. Central Research and Development Crops. Department of Research and Development of Agriculture, Bogor. [Indonesian]. 
Murdolelona, Dasilva B, Yusuf H. 2008. Adoption of Alley Cropping Technology on Dryland Farming System in Oesao area, Departmen of Agricultural Technology Assessment, Kupang, NTT. [Indonesian].

Olsen SR, Cole EV, Watanabe FS, Dean LA. 1954. Estimation of available $\mathrm{P}$ in soil by extraction with sodium bicarbonate. USDA Cir, pp 939-949.

Pratikno H, Syekhfani, Nuraini Y, Handayanto E. 2002. Utilization of biomass flora to improve the availability and absorption of $\mathrm{P}$ on calcareous soil at upstream brantas watershed area in Southern Malang. Biosain 2 (1): 78-91. [Indonesian].

Puspareny DA, Sumarni T, Nugroho A. 2008. The effect of Dosage and Period of Burying Green Manure of Orok Orok (Clitoria juncea L.) on Growth and Yield of Soybean. [Thesis]. Faculty of Agriculture, Universitas Brawijaya, Malang. [Indonesian].
SSIR.1984. Procedures for Collecting Soil Sample and Methods of Analysis for Soil Survey. Soil Survey Investigations Report No. 1, July 1984 (US Departement of Agriculture, Soil Conservation Service, USA).

Steel RGD, Torrie JH. 1989. The Principles and Procedures of Statistics, a Biometric Approach. PT Gramedia, Jakarta. [Indonesian].

Tisdale SL, Nelson WL, Beaton JD. 1985. Soil Fertility and Fertilizer. Macmillan, New York.

Walkley A. 1947. A Critical examination of rapid method for determining organic carbon in soils-effect of variations in digestion conditions and of inorganic soil constituents. Soil Sci 63: 251-264. DOI: 10.1097/00010694-194704000-00001 